\title{
Innovative Smart Phone Learning System for Graphical Systems within COVID-19 Pandemic
}

\author{
Ragad M Tawafak \\ Department of Information Technology, AlBuraimi University College, AlBuraimi, Oman \\ ORCID: 0000-0001-8969-1642 \\ Ghaliya Alfarsi \\ Department of Information Technology, AlBuraimi University College, AlBuraimi, Oman \\ College of Graduate Studies, University Tenaga Nasional, Malaysia \\ ORCID: 0000-0001-5038-0302 \\ Jasiya Jabbar \\ Department of Information Technology, AlBuraimi University College, AlBuraimi, Oman \\ ORCID: 0000-0003-3232-5013
}

Received: 11 Dec 2020

Accepted: 2 Mar 2021

\begin{abstract}
With restrictions on face-to-face clinical consultations within the COVID-19 pandemic and the challenges faced by healthcare systems in delivering patient care, alternative information technologies like telemedicine and smartphones play a crucial role. A wide variety of smartphone applications employs high-tech mathematical and programming approaches to enhance computer-assisted communication and learning processes' pedagogical efficiency. Accordingly, this study's main objective is to develop a model system that can function as smartphone computer graphics. This paper used the Technology Acceptance Model (TAM) as an m-learning model, and Bresenham's line algorithm is a calculation system implemented by applications. The study method applies technology to validate the accuracy of the contents' acceptance method of use. The results reveal significant positive effects of the proposed model on generating reasonable, fast, and accurate solutions for the presented problems and developing a more interactive platform of m-learning.
\end{abstract}

Keywords: computer graphics, algorithms, COVID-19, TAM

\section{INTRODUCTION}

The COVID-19 illness causes a broad scope of respiratory sickness from the regular virus to progressively severe disease, including pneumonia and the method of spreading, is dominatingly by bead spread (ALFarsi \& AlSinani, 2017; Davis, 1989; Mathew et al.,2019). To moderate the risk of personal face to face transmission of the coronavirus during the COVID-19 pandemic, different national governments have accessible broad 'lockdown' measures such as 'social removing' and 'protecting' of threat people (Alfarsi et al., 2019). Lockdown measures limit the development of individuals in networks while permitting essential administrations to control the spread of coronavirus episode. Thus, the impact of COVID-19 has had a critical effect of the daily life including human services furthermore, disturbance of monetary, social and flexibly chain parts (Mathew et al., 2019). 
Almost every field of education requires solving computational graphical problems. Computation is any type of calculation that may include either arithmetical or non-arithmetical steps or both and follows a welldefined model (Alfarsi et al., 2019; Davis, 1989). The study of mathematics is predominant in the discipline of computer science. Students, teachers, and researchers encounter problems to solve graphically regularly. Issues vary from simple and comfortable with a few steps to complex problems with many steps and estimations (Tawafak et al., 2020e). There is a wide variety of software to reduce the efforts required to deal with such problems, e.g., Microsoft Excel, and Wolfram Mathematica. Although these programs are readily available, such software requires substantial amounts of practice and knowledge (AlFarsi \& AlSinani, 2017; Mathew et al., 2019; Wong \& Sixl-Daniell, 2017).

Computers are astounding machines that help improve lives in terms of many aspects, and education with mobile learning assistance is one of them (Alfarsi et al., 2018, 2019; Muslichah, 2018). Some of the most important developments in education have happened since the advent of the information age. Nowadays, learners are well-versed in personal computers, laptops, smartphones, and electronic devices that support learners in their studies. Smartphones allow students to save their time and effort. The accessibility to mlearning modules can help enhance different ways of easy access and use (Alfarsi et al., 2017, 2020; Arshad \& Naseer, 2019). Therefore, users of the mobile learning model can obtain significant results for the algorithms selected outcomes in a short time and with less effort of the mind in conjunction with problemsolving smoothly (Barbieri et al., 2014; Davis, 1989). This work's prime focus is on implementing computational solutions for sub-net calculation and Bresenham's line algorithm (Fishbein \& Ajzen, 1977; Gumus, 2017).

Computer Assisted Learning (CAL) applications defined as the utilization of computers to help or support people's training or education (AlFarsi \& Yusof, 2020; García-Santillán \& Espinosa-Ramos, 2021; Hsieh, 2007; Wong \& Sixl-Daniell, 2017). M-learning models in education help reduce the time students need to understand and respond to learning experiences efficiently and innovatively. Thus, M-learning has become a universal method of learning and teaching (Tawafak et al., 2020e). Higher education institutions are mainly inclined to use Learning Management Systems (LMS) to improve face-to-face teaching. In this project, we use mobile learning as an application for converting some algorithms in IT courses. This study utilizes e-learning to help students solve problems and give accurate solutions (AlFarsi \& Yusof, 2020; Jabbar et al., 2020; Park, 2017; Tawafak et al., 2021, February).

The proposed application uses algorithms to process and produce solutions for related problems. The following issue addressed in this application of Bresenham's line algorithm-digitize a line with given endpoints. Accordingly, this paper attempts to answer the next question; "How can the proposed computational application model improve the effectiveness of the learning process?" (Malik et al., 2020). This algorithm helps students learn how to use practical algorithms with an individual run for each algorithm points and show the correct and significant results within a short time with high accuracy of values without using manual trails and error (Toquero, 2021).

This paper consists of several sections. It starts with the objectives of this study, followed by a literature review. Then, the methodology's discussion is going to present and followed by a description of data analysis or pre-questionnaire design and development. Finally, the system will evaluate. The paper concludes with a summary of the research work's findings, limitations, and recommendations for future research.

\section{LITERATURE REVIEW}

\section{Smartphone Technology}

A smartphone may be a newer class of radiophone with integrated technology and other features like an operating system, web browsing, also, the ability to run software applications. It called 'Smart' because they'll provide information after you need them at the touch of your fingers, which can utilize in a useful way (AlFarsi \& Yusof, 2020; Tawafak et al., 2020a; Van Raaij \& Schepers, 2008). Currently, smartphones are equipped with features like cameras, recording, Global Positioning Service (GPS) navigation, and games, sending and 
receiving an electronic message (email), web search applications for various purposes. SMT has influenced business, health, social life, education, and banking (Barbieri et al., 2014).

Computer science (the science of creating and designing computer hardware and software and their application in different fields) used through laptops or smartphones (Mathew et al., 2019). There is a branch for solving problems in general and mathematical issues, particularly by following the sequential steps of analyzing information related to a specific situation and generating suitable response options. The described steps understand the problem, create a model, develop an algorithm, write the program, test the program, and evaluate the solution (Alfarsi et al., 2020; Barbieri et al., 2014; Tawafak et al., 2019d).

Weng et al. conducted a study to understand the role and use of smartphones in Learning and Innovation practices. The study used five core practices like idea generation; market and technology surveillance; problem-solving; dialogue and knowledge transfer; training, and competence development. The methodology used a model based on ease of use, perceived usefulness (PU), and effectiveness (EFF) (Weng et al., 2018). The study's findings revealed the positive relationships between these factors and practising the author's method. The study concluded that smartphones contributed positively to firm capability (Wong \& Sixl-Daniell, 2017).

\section{E-Learning Systems}

E-learning systems are prevalent nowadays, which enable efficient teaching and learning approaches. Most researchers, such as (Alfarsi et al., 2019; Fishbein \& Ajzen, 1977; Tawafak et al., 2019b) have discussed the significance of e-learning as a teaching and learning approach and its relevance in emerging markets. The learning procedure is built based on various technological and learning factors like perceived ease of use (PEOU), perceived usefulness (PU), academic performance (AP), effectiveness (EFF), and satisfaction with the type of learning system and applications used. The findings strengthen four main areas for categorizing the preferred e-learning and communication tools in emerging markets, namely, course opening, course delivery, course assessment, and faculty attributes (Tatnall, 2020a; Wong \& Sixl-Daniell, 2017). E-Learning defined as a combination of face-to-face and online learning classes used to decrease classroom time. Also, to improve enjoyment and interest within education processes (Tatnall, 2020b). E-learning offers universities an opportunity to improve teaching methodologies and improve learning outcomes in universities (AlFarsi \& Yusof, 2020; Tawafak et al., 2019b).

Many models and theories are examining the technology adoption theories, including Theory of Planned Behaviour (TPB) by Muslichah (2018). Theory Acceptance Model (TAM) by Abramson (2015), and Theory of Reasoned Action (TRA) by Park (2017), and Booth et al. (2014). Besides, there is an extended version of TAM called TAM2. This version adds more factors to the original TAM to give more specific actual use (AU) of the model performance (Tatnall, 2020). That is why TAM2 used with two extended variables called self-efficiency (SE) and effectiveness (EFF). Accordingly, there is a need to develop a model responsible for technology acceptance when an assistance-learning tool improves learning and teaching interaction and continuity. This proposed outcome of the model linked with electronic components to aid in directing faculty members in the assessment method depending on their teaching pedagogy experience (Tawafak et al., 2020, December). Table 1 shows the existing studies related to e-learning that have used this study's common factors. Table 1 indicates that $(y)$ stands for elements used in the study. At the same time (x) signals, the studies that did not show any significant effects of the factors tested in the present study.

On the other hand, the blank cells determined the factors beyond this study's scope. Computer-Aided Learning (CAL) implemented in all areas of education. Software developed using multimedia technologies to create animation for a 3D model to simulate the assembling and disassembling process of High-speed flow shock tunnel (Tawafak et al., 2021).

In some colleges in Israel, they introduced introductory courses to undergraduate students who joined college and analyzed its importance. The study conducted to investigate, examine, and enhance students' skills to solve problems and develop algorithms. A group of students enrolled in a particular course with focused exercises about solving problems and improving related skills. Three aspects considered- the primary 
Table 1. The existing studies with commonly used factors

\begin{tabular}{|c|c|c|c|c|c|c|}
\hline Author & $\mathrm{PU}$ & PEOU & SE & $\mathrm{BI}$ & $\mathrm{AU}$ & EFF \\
\hline Tawafak et al. (2019d) & $Y$ & $Y$ & & $\mathrm{Y}$ & $Y$ & $x$ \\
\hline Fishbein and Ajzen (1977) & $Y$ & Y & Y & $\mathrm{Y}$ & Y & \\
\hline Jabbar et al. (2020) & Y & Y & $x$ & $\mathrm{Y}$ & Y & $Y$ \\
\hline Petiz et al. (2015) & $Y$ & Y & Y & $\mathrm{Y}$ & Y & \\
\hline Tawafak et al. (2019b) & Y & Y & & $\mathrm{Y}$ & Y & \\
\hline Tawafak et al. (2019c) & $Y$ & Y & & $\mathrm{Y}$ & Y & $Y$ \\
\hline Tawafak et al. (2018d) & Y & Y & Y & $\mathrm{Y}$ & Y & $x$ \\
\hline AlFarsi et al. (2018) & Y & Y & & & & $Y$ \\
\hline AlFarsi et al. (2020) & Y & Y & & $\mathrm{Y}$ & & $Y$ \\
\hline
\end{tabular}

talents they obtain in the time, the course's structure and content, and the desirable link between this course and the CS. The result considered good since many participants reported that they learned new skills and concepts during the time. (Tawafak et al., 2018c).

\section{DERIVED VARIABLES FOR THE STUDY}

This study tries to identify the main factors used in the e-learning model. There are six factors used in this study all of them derived from previous papers. As mentioned earlier in the literature review, these selected factors are highly recommended and used with TAM model and most existing m-learning models to evaluate the actual use and effectiveness of using smartphones as an easy m-learning application model. Besides, all these six factors used in different surveys, as shown in Table 1. these elements used by shorts Were PU: perceived usefulness, PEOU: perceived ease of use, SE: self-efficiency, BI: behaviour intention, AU: actual use, and EFF: effectiveness.

\section{BRESENHAM'S LINE ALGORITHM}

Bresenham's algorithm is an entire line drawing algorithm in computer graphics. It used to draw a line in a bitmap image; it uses only integer addition, subtraction, and bit shifting. A hybrid method defined as uses structural properties of raster lines to improve the efficiency of multi-point line generation. A quadruple-step algorithm developed requires fewer decision tests than other multi-point algorithms while retaining the multi-points advantage in pixel output efficiency, mainly when implemented in hardware (Tawafak et al., 2018c) visualization of Bresenham's Algorithm done using flash. The visualization used to explain how a line produced in a display computer for education. Flash movie demonstrates how Bresenham's Line Algorithm visualized by inputting data, performing calculations, and then returning the calculated results to an output text field. A sample of students was subject to this study and the data analyzed. The students' visualization and interactivity well tested, and the results indicated that students increased their ability to use program graphic applications (Tawafak et al., 2018a).

Drawing a circle on the screen is a little complex than drawing a line. There are two popular algorithms for generating a process; - Bresenham's Algorithm and Midpoint Circle Algorithm. These algorithms based on the idea of determining the subsequent points required to draw the circle. An efficient circle-drawing algorithm proposed by subdividing the activities into four major activities: moving into pixel space, tracing the process, forward differences, and bold second-order differences (Davis, 1989).

\section{METHOD}

This study aims to develop a new mobile application software as a learning model that generates a computational service intended for helping students with their graphical course. The model allows students to generate a correct and accurate solution quickly instead of manual calculations with a lot of mathematical work. There is a high chance of human errors implemented in the Information technology department at AlBuraimi University College (BUC). The plan was to develop an application to ease the understanding of 


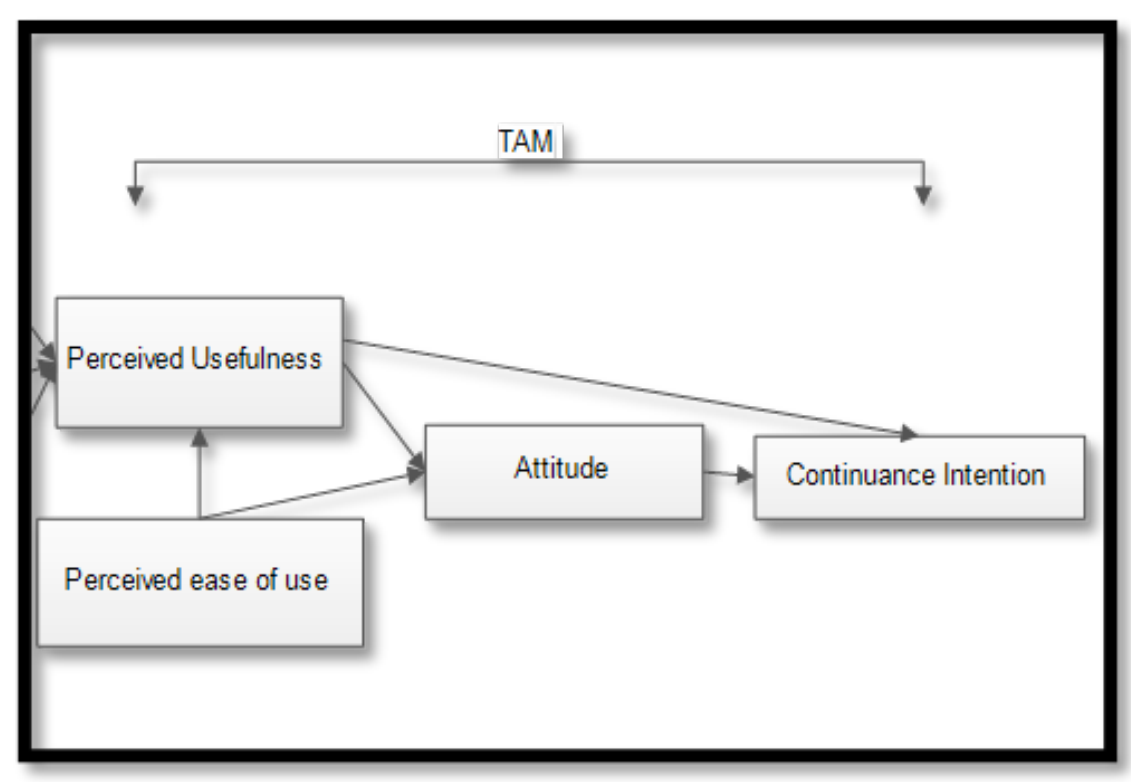

Figure 1. Technology Acceptance Model (TAM) (Abramson, 2015)

some specific topics and help them verify their solutions during their practices. The work started by reviewing the literature on some courses like computer graphics and computer architecture and design. Then, the research objectives set based on the algorithms selected in these areas.

In the proposed learning model, the model provides students with many tested and evaluated factors during any application system as a type of M-learning process. These factors are concerned with student perceptions, student motivation, perceived ease of use, perceived usefulness, and academic performance. Most of these factors can use with technology acceptance measurement (TAM) correctly (Alfarsi et al., 2020; García-Santillán \& Espinosa-Ramos, 2021; Muslichah, 2018). The TAM model, which is the most popular ELearning model, measures the significant positive effects of student perceptions, student motivation, and perceived ease of use, perceived usefulness, and academic performance the effectiveness of the applied system in enhancing the accuracy of students' performance (Alfarsi et al., 2020b; Rasslan et al., 2020).

The main problem determined in this paper is the lack of applications of such kinds of these algorithms. Therefore, faculty members need assisting tools for developing the academic performance of students. In this regard, perceived usefulness and perceived ease of use are the main influential factors of any computational or learning application (Fishbein \& Ajzen, 1977; Gumus, 2017).

To answer the research question, "How can the proposed computational application model improve the effectiveness of the learning process?" the authors built different hypotheses that tested the effectiveness of using a multi-algorithm of graphical course in the IT department. These algorithms help students learn how to use practical algorithms with an individual run for each algorithm point and show the correct and significant results within a short time with high accuracy of values without using manual trails and error.

A pre-questionnaire distributed among a sample of students to collect information about their requirements and suggestions on the software. It followed by the development and evaluation of the finished system. The application installed in labs in the college and a sample of students operated it. A post-questionnaire then distributed among students, who evaluated the system. The research model utilized, as shown in Figure 1.

Abramson (2015) defined perceived usefulness (PU) as people's belief regarding how new technology will enhance their learning performance. PU represents the system's subjective mechanism to assess the level of job performance enhancement and the degree of student progress in a course. Perceived ease of use (PEOU) defined as how students feel that e-learning models' application does not need any considerable efforts to use (Alfarsi et al., 2020; AlFarsi \& Yusof, 2020; Tawafak et al., 2018c). Effectiveness defined as the university's assessment scalability to measure the effective assessment with a continuous system used by different 
students. Academic performance defined as student activities to improve their grades using the application model (Tawafak et al., 2019d).

\section{Proposed Hypothesis}

Besides, the TAM model is performed and tested by PLS-SEM software to validate the reliability of motivating students and confirm the student perception toward using e-learning concurrently with attending regular classes to achieve the best results and trusted outcomes means of this application.

At this point, the researchers have come up with the following hypotheses:

H1: There is a positive influence between perceived usefulness and ease of use in the graphical learning model's smartphone.

$\mathrm{H} 2$ : There is a positive influence between perceived usefulness and behaviour intention in the graphical learning model's smartphone.

H3: There is a positive influence between perceived ease of use and behaviour intention in the graphical learning model's smartphone.

H4: There is a positive influence between self-efficiency and perceived usefulness in the graphical learning model's smartphone.

H5: There is a positive influence between self-efficiency and behaviour intention in the graphical learning model's smartphone.

H6: There is a positive influence between behavioural intention and actual use in the graphical learning model's smartphone.

H7: There is a positive influence between behavioural intention and effectiveness in the graphical learning model's smartphone.

H8: There is a positive influence between actual use and effectiveness in the graphical learning model's smartphone.

\section{Data Collection}

We selected the algorithms for generating the computational system from computer graphics and computer architecture and design-the students from Al Buraimi University College (BUC) chosen to fill in a questionnaire (Tawafak et al., 2019d). The students doing either the courses or have already done one or both the times. All of them are IT, students, from different levels and majors, including male and female final year students specializing in computer science, information systems, and software engineering-the questionnaire administered to 15 students randomly. Before the questionnaire administration, the participants briefed about the project, its goals, and the algorithms selected for implementation. Most of them had answers like strongly agree, agree, neutral, disagree, and strongly disagree. For some questions, they could choose multiple solutions-some of the problems mentioned below (Shakir et al., 2021). The questionnaire items developed on 5-points Likert scales to evaluate the accuracy of the questionnaire. Consequently, the following scales were employed; (Strongly agree $=5$, Agree $=4$, Neutral -3 , Disagree $=2$, and Strongly disagree=1). Table $\mathbf{2}$ shows the demographic representation of included random IT students at BUC. 
Table 2. Demographics information

\begin{tabular}{llcc}
\hline Field & Details & No. of Participant & Percentage \\
\hline College & BUC & 15 & $100 \%$ \\
\hline Department & IT & 15 & $100 \%$ \\
\hline Major & IS & 8 & 0.54 \\
& CS & 4 & 0.27 \\
& SE & 3 & 0.2 \\
\hline Age & $18-23$ & 9 & 0.6 \\
& Above 23 & 6 & 0.4 \\
\hline Interesting Course & Graphic Course & 7 & 0.46 \\
& Others & 8 & 0.54 \\
\hline Internet Use & High & 10 & 0.7 \\
& Low & 5 & 0.3 \\
\hline
\end{tabular}

Table 3. Data analysis indicator of participants

\begin{tabular}{lcccc}
\hline Item & Mean & Standard Deviation & Excess Kurtosis & Skewness \\
\hline PU1 & 4.208 & 0.788 & -0.857 & -0.508 \\
PU2 & 4.117 & 0.880 & -1.024 & -0.462 \\
PU3 & 4.28 & 0.731 & -0.519 & -0.843 \\
PU4 & 4.367 & 0.694 & -0.147 & -0.758 \\
PEOU1 & 4.023 & 0.606 & -0.473 & -0.628 \\
PEOU2 & 4.231 & 0.677 & 0.368 & -0.905 \\
PEOU3 & 4.316 & 0.783 & 0.365 & -0.807 \\
EF1 & 4.101 & 0.680 & 0.726 & -0.566 \\
EF2 & 4.443 & 0.717 & 0.896 & -0.425 \\
EF3 & 4.257 & 0.763 & -0.080 & -0.738 \\
SE1 & 0.573 & 0.433 & -1.043 \\
SE2 & 4.104 & 0.596 & -0.783 & -0.87 \\
SE3 & 4.098 & 0.628 & 0.458 & -0.353 \\
BI1 & 4.14 & 0.880 & 0.339 & -.0 .441 \\
BI2 & 4.03 & 0.731 & -0.458 & -0.679 \\
BI3 & 4.470 & 0.694 & -0.932 & -1.043 \\
AU1 & 3.980 & 0.843 & -0.510 & -0.873 \\
AU2 & 3.982 & 0.871 & 0.250 & -0.353
\end{tabular}

\section{Data Analysis}

The questions of items sent to expert evaluators at BUC from the English Department validate the language grammar and the easy of statements to understand by students. The survey also sent an IT expert from the IT department to check the right selections of the items related to the paper title and the purpose of this survey. Table 3 shows the results of testing these items using the PLS-SEM program. This program evaluates the real values of mean, standard deviation, Excess Kurtosis, and skewness values (Tawafak et al., 2020e). As explained in Table 3, all results came out as accepted values and above the needed.

\section{RESULTS AND DISCUSSION}

After the survey distributed between the selected populations, the partial Least Structure Square-Equation Measurement PLS-SEM, in this program, many operations used to test the model's validity and reliability (Tawafak et al., 2018c). 
Table 4. Factors tests of Alpha, Composite reality and AVE

\begin{tabular}{|c|c|c|c|c|c|}
\hline Factor & Item & Load & Alpha & CR & AVE \\
\hline \multirow[t]{3}{*}{ Effectiveness } & EF1 & 0.630 & \multirow{3}{*}{0.754} & \multirow{3}{*}{0.807} & \multirow{3}{*}{0.680} \\
\hline & EF2 & 0.725 & & & \\
\hline & EF3 & 0.913 & & & \\
\hline \multirow[t]{2}{*}{ Perceived Ease of Use } & PEOU1 & 0.832 & \multirow{2}{*}{0.709} & \multirow{2}{*}{0.826} & \multirow{2}{*}{0.704} \\
\hline & PEOU2 & 0.846 & & & \\
\hline \multirow[t]{2}{*}{ Self-efficiency } & SE2 & 0.849 & \multirow{2}{*}{0.813} & \multirow{2}{*}{0.826} & \multirow{2}{*}{0.704} \\
\hline & SE3 & 0.828 & & & \\
\hline \multirow[t]{3}{*}{ Perceived Usefulness } & PU1 & 0.765 & \multirow{3}{*}{0.943} & \multirow{3}{*}{0.904} & \multirow{3}{*}{0.703} \\
\hline & PU2 & 0.908 & & & \\
\hline & PU3 & 0.823 & & & \\
\hline \multirow[t]{3}{*}{ Behaviour Intention } & $\mathrm{BI} 1$ & 1.000 & \multirow{3}{*}{0.950} & \multirow{3}{*}{0.870} & \multirow{3}{*}{0.760} \\
\hline & $\mathrm{BI} 2$ & 0.580 & & & \\
\hline & $\mathrm{BI} 3$ & 0.702 & & & \\
\hline \multirow[t]{2}{*}{ Actual Use } & AU1 & 1.000 & \multirow{2}{*}{0.804} & \multirow{2}{*}{0.900} & \multirow{2}{*}{0.840} \\
\hline & AU2 & 0.580 & & & \\
\hline
\end{tabular}

Table 5. $R^{2}$ results

\begin{tabular}{ll}
\hline Factor & $\mathrm{R}^{2}$ \\
\hline PEOU & 0.307 \\
PU & 0.258 \\
BI & 0.220 \\
AU & 0.590 \\
EFF & 0.472 \\
\hline
\end{tabular}

Table 4 shows the item loading of each constructed instrument. The accepted values of loading factors should be above 0.6 to be validated value, and the model classified as an acceptable model. Besides, Table 4, shows the results of Alpha value, as mentioned by all authors who used PLS-SEM program, the right results should be above 0.7 to be accepted. One more test operation used from evaluating the mixed reality (CR) of each factor. The obtained result should be above 0.7 to derive the model in successful influence and significant positive relationship (Tawafak et al., 2020e). Lastly, Table 5 tested AVE values, and this factor should be above 0.5 for all elements used in the model.

When these results compared to other researchers' previous achievements from the derived factors shown in Table 1, this study almost figured out the same active and significant results at all six essential elements with their influence based on the research model explained in Figure 2. Although, the products are accepted enough as what others achieved (AlFarsi \& Yusof, 2020; Fishbein \& Ajzen, 1977; García-Santillán \& EspinosaRamos, 2021; Hsieh, 2007; Jabbar et al., 2020; Tawafak et al., 2018c; Wong \& Sixl-Daniell, 2017). still this study provides a novelty and improvement of the outputs for the following reasons:

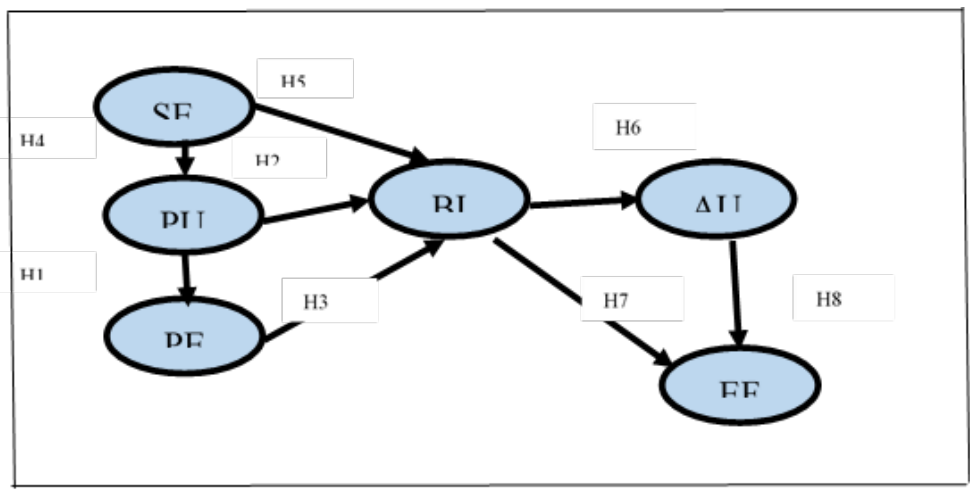

Figure 2. Model Hypothesis 
Table 6. Path coefficient

\begin{tabular}{|c|c|c|c|c|}
\hline No. & Hypothesis relationship & B test & Path coefficient & Remarks \\
\hline $\mathrm{H} 1$ & $\mathrm{PU} \rightarrow \mathrm{PEOU}$ & 0.210 & $P<0.001$ & accepted \\
\hline $\mathrm{H} 2$ & $\mathrm{PU} \rightarrow \mathrm{BI}$ & 0.159 & $P<0.001$ & accepted \\
\hline H3 & $\mathrm{PEOU} \rightarrow \mathrm{BI}$ & 0.203 & $P<0.001$ & accepted \\
\hline $\mathrm{H} 4$ & $\mathrm{SE} \rightarrow \mathrm{PU}$ & 0.160 & $P<0.001$ & accepted \\
\hline H5 & $\mathrm{SE} \rightarrow \mathrm{BI}$ & 0.134 & $P<0.001$ & accepted \\
\hline H6 & $\mathrm{BI} \rightarrow \mathrm{AU}$ & 0.178 & $P<0.001$ & accepted \\
\hline $\mathrm{H7}$ & $\mathrm{Bl} \rightarrow \mathrm{EFF}$ & 0.251 & $P<0.001$ & accepted \\
\hline $\mathrm{H} 8$ & $\mathrm{AU} \rightarrow \mathrm{EFF}$ & 0.230 & $P<0.001$ & accepted \\
\hline
\end{tabular}

1. This research proposed a novel model with new connections among essential elements and the new influence that pointed in hypotheses $\mathrm{H} 4, \mathrm{H} 5, \mathrm{H} 6, \mathrm{H} 7$, and $\mathrm{H} 8$.

2. This research came out with all supported and significant influence from all research hypotheses.

3. The validity and success of $\mathrm{H} 7$, and $\mathrm{H} 8$ that includes elements of self-efficient, behaviour intention and actual use with the effectiveness of the visual system that can easily use and monitored from smartphones.

4. Table $\mathbf{4}$ shows the values of Alpha, $C R$, and AVE factors more reliable and evidence of the model powerful among elements and their influence to get the effective use of the visual system.

Table 5 explains the $\mathrm{R}^{2}$ achieved between relationship and factor determinant loading. All the results achieved were positive and accepted because it is above the limit of being above 0.1. Both factor AU and EFF have an excellent product at $R^{2}$ of the testing model. Table 5 shows the path coefficient of data results from the PLS-SEM program.

Table 5 shows the values of $r$ square have different impact outputs. If $R$ square results greater than 0.2 , it gives good acceptance, while $R$ square results greater than 0.4 show that excellent acceptance. As mentioned in Table 5, the influence of R square of actual use (AU) and effectiveness (EFF) is above 0.4, and these are the endpoint target of the research model tested in this study.

One more value should test to validate the significance of model elements, the $B$ test needed for this purpose. All matters of B test if greater than 0.1 it indicates good results from PLS-SEM program. Table 6 shows the real additional tests and the active effects of the $B$ test and the path coefficient for all is less than 0.001 that give remarks of supporting element and accepted results.

\section{CONCLUSION}

This paper tries to develop the e-learning model's development with the converting numbering system and the visual system. The application uses algorithms to address the essential factors used by m-learning and produce solutions to reduce calculation time using Bresenham Line Algorithm. This algorithm helps students learn how to use practical algorithms while individually running each algorithm's points and showing correct and significant results within a short time with high accuracy of values without using manual and error paths. These two application systems commonly used in courses related to the IT department in all BUC majors and most IT universities worldwide. The paper used an adapted TAM model with extra variables like self-efficiency and effectiveness to get more trust and interest results on testing the model. Many variables used to test model satisfaction and acceptance. The paper reveals the significant positive supports of all eight hypotheses given in this paper. This paper's researchers recommended enhancing more smartphone applications to convert most of the graphical systems to easy applications for implementing good results in the shortest time and minimum efforts.

Author contributions: All authors were involved in concept, design, collection of data, interpretation, writing, and critically revising the article. All authors approve final version of the article. 
Funding: The authors received no financial support for the research and/or authorship of this article.

Declaration of interest: Authors declare no competing interest.

Data availability: Data generated or analysed during this study are available from the authors on request.

\section{REFERENCES}

Abramson, T. A. (2015). Older adults: the "Panini Sandwich" generation. Clinical Gerontologist, 38(4), 251267. https://doi.org/10.1080/07317115.2015.1032466

Al Farsi, G., Jabbar, J., Tawafak, R. M., Malik, S. I., Alsidiri, A., \& Alsinani, M. (2020). Mobile Application System Supported BUC Students Services and Learning. International Journal of Interactive Mobile Technologies, 14(9), 79-94. https://doi.org/10.3991/ijim.v14 i09.12053

AlFarsi, G. M. S., Omar, K. A. M., \& Alsinani, M. J. (2017). A rule-based system for advising undergraduate students. Journal of Theoretical \& Applied Information Technology, 95(11), 2453-2465.

ALFarsi, G., \& AlSinani, M. (2017). Developing a mobile notification system for al Buraimi University College students. International Journal of Information Technology, 1(1), 10-16.

AlFarsi, G., \& Yusof, A. B. M. (2020, November). Virtual Reality Applications in Education Domain. In 2020 21st International Arab Conference on Information Technology (ACIT) (pp. 1-7). IEEE. https://doi.org/10.1109/ACIT50332.2020.9300056

AlFarsi, G., Jabbar, J., \& AlSinani, M. (2018). Implementing a Mobile Application News Tool for Disseminating Messages and Events of AlBuraimi University College. International Journal of Interactive Mobile Technologies (iJIM), 12(7), 129-138. https://doi.org/10.3991/ijim.v12i7.9484

Alfarsi, G., Jabbar, J., Tawafak, R. M., Malik, S. I., Alsidiri, A., \& Alsinani, M. (2019). Using Cisco Packet Tracer to simulate smart home. International Journal of Engineering Research \& Technology, 8(12), 670-674. https://doi.org/10.1109/ACIT47987.2019

Alfarsi, G., Yusof, A. B. M., Tawafak, R. M., Malik, S. I., Mathew, R., \& Ashfaque, M. W. (2020a, December). Instructional Use of Virtual Reality in E-Learning Environments. In 2020 IEEE International Conference on Advent Trends in Multidisciplinary Research and Innovation (ICATMRI) (pp. 1-5). IEEE.

Alfarsi, G., Yusof, A. B. M., Tawafak, R. M., Malik, S. I., Mathew, R., \& Ashfaque, M. W. (2020b, December). An Overview of Electronic Games in the Academic Areas. In 2020 IEEE International Conference on Advent Trends in Multidisciplinary Research and Innovation (ICATMRI) (pp. 1-6). IEEE.

Arshad, R., \& Naseer, M. (2019). Digital Transformation in Marketing Mobile Phones Industry: Evaluating Marketers Strategies for Cross-Cultural Advertisements. Online Journal of Communication and Media Technologies, 9(3), e201915. https://doi.org/10.29333/ojcmt/5841

Booth, J. L., Barbieri, C., Eyer, F., \& Paré-Blagoev, E. J. (2014). Persistent and pernicious errors in algebraic problem solving. The Journal of Problem Solving, 7(1), 3. https://doi.org/10.7771/1932-6246.1161

Davis, F. D. (1989). Perceived usefulness, perceived ease of use, and user acceptance of information technology. MIS quarterly, 13(3), 319-340. https://doi.org/10.2307/249008

Fishbein, M., \& Ajzen, I. (1977). Belief, attitude, intention, and behavior: An introduction to theory and research. Addison-Wesley.

García-Santillán, A., \& Espinosa-Ramos, E. (2021). Addiction to the Smartphone in High School Students: How It's in Daily Life?. Contemporary Educational Technology, 13(2), ep296. https://doi.org/10.30935/cedtech/9609 
Gumus, N. (2017). Determination of Smartphone Users' Perceptions of Branded Mobile Applications in Turkey. Online Journal of Communication and Media Technologies, 7(3), 27-45. https://doi.org/10.29333/ojcmt/2598

Hsieh, W. H. (2007). An experimental study on cam-controlled planetary gear trains. Mechanism and Machine Theory, 42(5), 513-525. https://doi.org/10.1016/j.mechmachtheory.2006.10.006

Jabbar, J., Malik, S. I., AlFarsi, G., \& Tawafak, R. M. (2020). The Impact of WhatsApp on Employees in Higher Education. In Recent Advances in Intelligent Systems and Smart Applications (pp. 639-651). Springer. https://doi.org/10.1007/978-3-030-47411-9_34

Malik, S., Al-Emran, M., Mathew, R., Tawafak, R., \& AlFarsi, G. (2020). Comparison of E-Learning, M-Learning and Game-based Learning in Programming Education-A Gendered Analysis. International Journal of Emerging Technologies in Learning (iJET), 15(15), 133-146. https://doi.org/10.3991/ijet.v15i15.14503

Mathew, R., Malik, S. I., \& Tawafak, R. M. (2019). Teaching Problem Solving Skills using an Educational Game in a Computer Programming Course. Informatics in Education, 18(2), 359-373. https://doi.org/10.15388/infedu.2019.17

Muslichah, M. (2018). The effect of self efficacy and information quality on behavioral intention with perceived usefulness as intervening variable. Journal of Accounting, Business and Management (JABM), 25(1), 21-34. https://doi.org/10.31966/jabminternational.v1i25.327

Park, C. S. (2017). Unpacking the Relationship between Mobile Phone Usage Patterns, Network Size, and Civic Engagement. Online Journal of Communication and Media Technologies, 7(2), 169-197. https://doi.org/10.29333/ojcmt/2596

Petiz, S., Ramos, F., \& Roseiro, P. (2015). The use of information and communication technologies in organizational learning practices: A research study in an innovation-oriented Portuguese organization. International Journal of Advanced Corporate Learning, 8(1), 4. https://doi.org/10.3991/ijac.v8i1.3602

Rasslan, S., Shibli, N., \& Rasslan-Sharif, A. (2020). Virtual School Students' Reactions to Understanding Tasks: The Case of Local Extrema Point. Contemporary Mathematics and Science Education, 1(2), ep20007. https://doi.org/10.30935/conmaths/8496

Saleem, H. (2005). Antecedents of computer self-efficacy and behavioral intention to use new IT: An investigation of the role of personality traits (Doctoral dissertation, Concordia University).

Shakir, M., Abood, R., Sheker, M., Alnaseri, M., Al-Hashimi, M., \& Tawafak, R. M. (2021). Users Acceptance of Electronic Personal Synthesis Behavior (EPSB): An Exploratory Study. Recent Advances in Technology Acceptance Models and Theories, 509-520.

Tatnall, A. (2019). Editorial for EAIT issue 2, 2019. Education and Information Technologies, 24(2), 953-962. https://doi.org/10.1007/s10639-019-09874-7

Tatnall, A. (2020a). Correction to: Editorial for EAIT issue 2, 2020. Education and Information Technologies, 25, 5901-5910. https://doi.org/10.1007/s10639-020-10180-w

Tatnall, A. (2020b). Editorial for EAIT issue 2, 2020. Education and Information Technologies, 25(2), 647-657. https://doi.org/10.1007/s10639-020-10135-1

Tawafak, R. M. (n.d.). The Comprehension Theories of Continuous Intention to Use Tel with e-learning Models in Educations. Table of Content Id Title Author, 41.

Tawafak, R. M., Alfarsi, G., AINuaimi, M. N., Eldow, A., Malik, S. I., \& Shakir, M. (2020a, April). Model of Faculty Experience in E-Learning Student Satisfaction. In 2020 International Conference on Computer Science and Software Engineering (CSASE) (pp. 83-87). IEEE. https://doi.org/10.1109/csase48920.2020.9142071 
Tawafak, R. M., Alfarsi, G., Malik, S. I., AlNuaimi, M. N., Shakir, M., \& Ashfaque, M. W. (2020, December). Coverage COVID 19 with E-Learning Replacement. In 2020 IEEE International Conference on Advent Trends in Multidisciplinary Research and Innovation (ICATMRI) (pp. 1-5). IEEE.

Tawafak, R. M., Alfarsi, G., Malik, S. I., Eldow, A., Jabbar, J., \& Alsideiri, A. (2020b, September). Cancer Treatment Disease Application Software Technology in Medicine. In 2020 IEEE Student Conference on Research and Development (SCOReD) (pp. 380-384). IEEE. https://doi.org/10.1109/SCOReD50371.2020

Tawafak, R. M., Alfarsi, G., Romli, A., Jabbar, J., Malik, S. I., \& Alsideiri, A. (2020c, September). A Review Paper on Student-Graduate Advisory Expert system. In 2020 International Conference on Computing and Information Technology (ICCIT-1441) (pp. 1-5). IEEE. https://doi.org/10.1109/iccit144147971.2020.9213794

Tawafak, R. M., AlSideir, A., Alfarsi, G., Al-Nuaimi, M. N., Malik, S. I., \& Jabbar, J. (2019a). E-learning Vs. Traditional Learning for Learners Satisfaction. E-learning, 29(3), 388-397.

Tawafak, R. M., Malik, S. I., \& Alfarsi, G. (2020d). Development of framework from adapted TAM with MOOC platform for continuity intention. Development, 29(1), 1681-1691.

Tawafak, R. M., Mohammed, M. N., Arshah, R. B. A., \& Romli, A. (2018a, February). Review on the effect of student learning outcome and teaching Technology in Omani's higher education Institution's academic accreditation process. In Proceedings of the 2018 7th International Conference on Software and Computer Applications (pp. 243-247). https://doi.org/10.1145/3185089.3185108

Tawafak, R. M., Mohammed, M. N., Arshah, R. B. A., Shakir, M., \& Mezhuyev, V. (2018b). Technology enhancement learning reflection on improving Students' Satisfaction in Omani Universities. Advanced Science Letters, 24(10), 7751-7757. https://doi.org/10.1166/asl.2018.13012

Tawafak, R. M., Romli, A. B., \& Arshah, R. B. A. (2019b, February). E-learning Model for Students' Satisfaction in Higher Education Universities. In 2019 International Conference on Fourth Industrial Revolution (FIR) (pp. 1-6). IEEE. https://doi.org/10.1109/icfir.2019.8894778

Tawafak, R. M., Romli, A. B., \& Arshah, R. B. A. (2018c). Continued Intention to Use UCOM: Four Factors for Integrating with a Technology Acceptance Model to Moderate the Satisfaction of Learning. IEEE Access, 6, 66481-66498. https://doi.org/10.1109/access.2018.2877760

Tawafak, R. M., Romli, A. B., bin Abdullah Arshah, R., \& Almaroof, R. A. S. (2018d). Assessing the impact of technology learning and assessment method on academic performance. EURASIA Journal of Mathematics, Science and Technology Education, 14(6), 2241-2254. https://doi.org/10.29333/ejmste/87117

Tawafak, R. M., Romli, A. B., bin Abdullah Arshah, R., \& Malik, S. I. (2019c). Framework design of university communication model (UCOM) to enhance continuous intentions in teaching and e-learning process. Education and Information Technologies, 25, 817-843. https://doi.org/10.1007/s10639-019-09984-2

Tawafak, R. M., Romli, A. M., \& Alsinani, M. J. (2019d). Student Assessment Feedback Effectiveness Model for Enhancing Teaching Method and Developing Academic Performance. International Journal of Information and Communication Technology Education (IJICTE), 15(3), 75-88. https://doi.org/10.4018/ijicte.2019070106

Tawafak, R. M., Romli, A., \& Arshah, R. A. (2019e, August). E-learning prospect on improving academic performance in Omani Universities. In IOP Conference Series: Materials Science and Engineering (Vol. 551, No. 1, p. 012033). IOP Publishing. https://doi.org/10.1088/1757-899x/551/1/012033

Tawafak, R. M., Romli, A., Malik, S. I., Alfarsi, G., \& Jabbar, J. (2021, February). Examining continuous integrating of technology acceptance model with task-technology fit. In IOP Conference Series: Materials Science and Engineering (Vol. 1088, No. 1, p. 012061). IOP Publishing. 
Tawafak, R. M., Romli, A., Malik, S. I., Shakir, M., \& Alfarsi, G. M. (2019f). A systematic review of personalized learning: Comparison between E-learning and learning by coursework program in Oman. International Journal of Emerging Technologies in Learning (iJET), 14(09), 93-104. https://doi.org/10.3991/ijet.v14i09.10421

Tawafak, R., AlFarsi, G., Jabbar, J., Malik, S. I., Mathew, R., AlSidiri, A., Shakir, M., \& Romli, A. (2021). Impact of Technologies During COVID-19 Pandemic for Improving Behavior Intention to Use E-learning. International Journal of Interactive Mobile Technologies, 15(1), 184-198 https://doi.org/10.3991/ijim.v15i01.17847

Tawafak, R., Romli, A., Malik, S., \& Shakir, M. (2020e). IT Governance Impact on Academic Performance Development. International Journal of Emerging Technologies in Learning (iJET), 15(18), 73-85. https://doi.org/10.3991/ijet.v15i18.15367

Toquero, C. M. D. (2021). Mobile Healthcare Technology for People with Disabilities amid the COVID-19 pandemic. European Journal of Environment and Public Health, 5(1), em0060. https://doi.org/10.29333/ejeph/8551

Van Raaij, E. M., \& Schepers, J. J. (2008). The acceptance and use of a virtual learning environment in China. Computers \& education, 50(3), 838-852. https://doi.org/10.1016/j.compedu.2006.09.001

Weng, F., Yang, R. J., Ho, H. J., \& Su, H. M. (2018). A TAM-based study of the attitude towards use intention of multimedia among school teachers. Applied System Innovation, 1(3), 36. https://doi.org/10.3390/asi1030036

Wong, A., \& Sixl-Daniell, K. (2017). The Importance of e-Learning as a Teaching and Learning Approach in Emerging Markets. iJAC, 10(1), 45-54. https://doi.org/10.3991/ijac.v10i1.6471

Correspondence: Ragad M Tawafak, Department of Information Technology, AlBuraimi University College, AlBuraimi, Oman. E-mail: raghad@buc.edu.om 